\title{
REKONSTRUKSI TEOLOGI RADIKALISME DI INDONESIA, MENUJU ISLAM RAHMATAN LIL-ALAMIN
}

\author{
Jamal Ma'mur Asmani, ${ }^{1}$ \\ Institut Pesantren Mathali'ul Falah (IPMAFA) Pati \\ email: jamal_mamur@yahoo.com
}

\begin{abstract}
Abstraksi
Religious radicalism nowaday has became a major world threat. Religious radicalism has been able to indoctrinate people until they commit extremist acts that may harm other and leads into series, including life and wealth. The process of religious radical indoctrination comes from the claim of exclusive truth. Where they believed, Islam and its understanding is one, that is what they understood and practice during the life of the prophet Muhammad SAW.

Jihad is understood as jihad with the soul and property by taking up arms to quell extinguish kufr and polytheism on earth. The slogan Isy Kariman or mut syahidan (noble life or martyrdom) encourage them to quell any disobedience. Tolerating kufr and polytheism considering as allowing infidelity threatened with great punishment. The only way to overcome infidelity through mobilizing all possible capabilities and means for the glory of Islam.

This theology their soul is contrary to the spirit of diversity, as one important ideology for the Indonesian society and also contrary to the philosophy of Islam as a religion that bring mercy to all human kind. Qur'an in many places assert that faith is the right prerogative of god cannot be interfered with anyone, so that a person is forbidden to hate others because of differences in beliefs. Prophet Muhammad SAW. set a good example when lead humanity in Madina by issuing the Charter of Medina.

The Charter of Medina who inspire and motivate Walisongo to preach Islam as a peaceful, tolerant and progressive, not by violence, intimidation, threats, and justifies any means. History proved, Walisongo is method of islamic propagation have proven as an effective way to convert many millions of Java
\end{abstract}

1 Dosen Institut Pesantren Mathali'ul Falah (IPMAFA) Pati Jawa Tengah, Hp. 085726836184, email: jamal_ mamur@yahoo.com 
heterogeneous and pluralistic. Although Hinduism and Buddhism are already secure hegemony, but through gentleness, modesty, and exemplary Walisongo, Islam have penetrated into life of into massive islamic conversion, without any compulsion, threat on intimidation.

This is the implementation as Islam rahmatan lil'Alamin that become true characteristic of the spirit as plural and heterogeneous society. Depart, from this context, there should be urgent needs to reconstruct fundamentalist ideologies of exclusiveness, through major strategic theological steps.

Keywords: radicalism, Islam, rahmatan lil'Alamin, reconstruction, tolerant.

\section{A. Pendahuluan}

Ekspansi gerakan ISIS (Islamic State of Irak and Syiria) ke berbagai Negara, tidak hanya di Timur Tengah, membawa kegelisahan umat Islam dan seluruh umat manusia. Mereka khawatir ada salah satu warga negaranya yang berhasil direkrut ISIS dan menjadi martir dalam melakukan agenda kelompok radikal yang membahayakan keselamatan dan keamanan umat manusia di berbagai penjuru dunia. Berbagai insiden radikal dan teror yang terjadi, baik di Jakarta, Perancis, Pakistan, dan Turki menghentakkan dunia akan bahaya radikalisme. ISIS adalah satu dari puluhan kelompok radikal yang harus diwaspadai karena kelompok-kelompok ini terus melakukan kaderisasi massif di berbagai belahan dunia.

Memahami karakteristik kelompok ini sangat penting untuk mengidentifikasi keberadaannya. Kelompok radikal ini mempunyai karakteristik pemahaman agama yang eksklusif dan monolog. Secara lebih detail, menurut Nash Hamid Abu Zayd, seperti dikutip M. Guntur Romli, ada lima ciri pola wacana keagamaan yang tertutup. Pertama, menyatukan antara agama dan pemikiran. Jarak pemisah antara agama dan hasil pemahaman agama (ijtihad) terhadap agama tidak bisa dipisahkan dengan jelas, sehingga ketika ada pemahaman lain yang bertentangan dengan pemahamannya dianggap melanggar agama.

Kedua, teologisasi fenomena sosial dan alam. Dalam wacana ini, hukum kausalitas (sebab-musabab) tidak dilihat sebagai faktor utama. Semua kejadian, baik berupa realitas sejarah atau sosial, dikembalikan kepada Allah. Pemahaman ini mendorong manusia untuk malas dan kehilangan etos kerja yang tinggi dan lebih bersifat fatalis. Ketiga, interdependensi (ketergantungan) terhadap "salaf" dan "tradisi" (turast). Kelompok ini memandang masa lalu adalah segala-galanya. Hasil karya ulama terdahulu sudah melebihi dari cukup dan tugas generasi sekarang hanya mempraktekkannya. Perbedaan pendapat tidak dihargai jika bertentangan dengan tradisi dan pendapat ulama salaf.

Dalam pandangan mereka, agama adalah tradisi kaum salaf dan jika bertentangan dengan mereka maka dianggap menyimpang dari agama. Keempat, fanatisme pendapat dan menolak dialog. Setelah kelompok ini berlindung di balik tradisi (turast), mereka memiliki otoritas tersendiri untuk menafsirkan tradisi-tradisi. Otoritas ini hanya dimiliki kelompok mereka, sedangkan kelompok lain tidak memiliki kebebasan untuk menafsirkannya. Kelima, 
mengingkari dimensi historis (sejarah). Pola berpikir ini sebagai akibat dari pola-pola di atas. Hukum perubahan dan pergantian dipahami dari aspek teologi, bukan sebagai proses sejarah dan sosial. Tidak jarang, konsep-konsep yang mulanya tidak ada dalam ajaran Islam diyakini sebagai ajaran agama karena memiliki sejarah dan terjadi di komunitas Islam, seperti konsep "Negara Islam" (al-Khilafah al-Islamiyah) yang dimulai dari Dinasti Umawiyah di Damakus (Syria) hingga Dinasti Utsmaniyah di Istanbul (Turki). ${ }^{2}$

Lima karakteristik ini ada pada kelompok ISIS dan kaum radikal lainnya. Lima karakter ini ditanamkan pada seluruh anggotanya, sehingga proses indoktrinasi dan kaderisasi berjalan sukses sehingga anggota kelompok mereka siap menjadi martir-martir yang rela menyerahkan jiwa dan raga untuk melakukan tugas suci, yaitu jihad di jalan Allah, baik dengan bom bunuh diri atau mengangkat senjata melawan orang-orang kafir yang menurut mereka harus dibunuh. Di sinilah urgensi mengkaji akar teologi kaum radikal untuk memahami lebih mendalam penyebabnya, kemudian melakukan rekonstruksi teologsi untuk merumuskan pemikiran Islam yang relevan untuk dunia kontemporer sekarang, yaitu Islam rahmatan li-alamin. Upaya ini dilakukan dengan tujuan mengeleminir potensi berkembangnya kaum radikalis. Jangan sampai di tengah pertarungan ideologi dunia, kelompok radikal menjadi mainstream ideologi Islam Indonesia karena membahayakan nilai-nilai substansial Islam yang berciri damai, toleran, sejuk, dan santun.

\section{B. Radikalisme di Era Kontemporer}

Menurut As'ad Said Ali, pertarungan ideologi dunia terus berlangsung dalam skala global dan sudah masuk ke Indonesia dengan aksi bom di beberap daerah. ${ }^{3}$ Secara konseptual, ideologisasi dalam Islam, muncul ketika beberapa wilayah Islam berhadapan dengan modernisme Barat. Muncullah Jamaluddin al-Afghani, Mohammad Abduh dan Rasyid Ridla yang melahirkan nasionalisme di Timur Tengah. ${ }^{4}$ Banyak faktor yang melatarbelakangi lahirnya ideologi radikal. Pertama, semangat pemurnian ajaran agama. Kedua, ajaran Islam harus diimplementasikan secara konkret dalam realitas kehidupan. Ketiga, membendung pengaruh Barat dengan nilainilai yang dipandang tidak relevan dengan ajaran Islam, seperti matrealisme, individualisme, hedonisme, dan sekularisme. ${ }^{5}$ Ekspansi ideologi radikal di Indonesia sudah berlangsung lama. Sebagai Negara dengan penduduk muslim terbesar dunia, potensi radikalisme juga sangat besar dengan model indoktrinasi yang berjalan secara sistematis.

Akhirnya, Indonesia sekarang terkenal dengan negara teroris karena perilaku segelintir orang yang menghalalkan darah manusia. Ironisnya mereka mengatasnamakan aksi sadisnya dengan jihad. Obyek yang terbunuh bukanlah kafir harbi yang wajib diperangi, tapi fasilitas umum dan orang-orang yang bersalah, meskipun ada juga sasarannya tempat-tempat maksiat.

2 M. Guntur Romli, Membongkar Mitos Sejarah: Konflik Sosial dan Agama, 2001, Jakarta: Tashwirul Afkar Lakpesdam, edisi 11, hlm. 125-127

3 As'ad Said Ali, 2009, Negara Pancasila Jalan Kemaslahatan Bangsa, Jakarta: LP3ES, cet. 2, hlm. 265

4 As'ad Said Ali, 2009, Negara Pancasila Jalan Kemaslahatan Bangsa, Jakarta: LP3ES, cet. 2, hlm. 290-291

5 Ahwan Fanani, 2013, Liberalisme Islam Di Indonesia, Semarang: Pustaka Zaman \& Fakultas Ilmu Tarbiyah dan Keguruan IAIN Walisongo, hlm. 43-44 
Namun cara yang digunakan jelas bertentangan dengan hukum Allah yang harus menebarkan kasih sayang dan kedamaian kepada sesama. Sedangkan pengertian jihad adalah berjuang di jalan Allah baik dengan berperang, menyampaikan argumen-argumen agama yang benar untuk meluruskan pemikiran dan aliran yang sesat, melindungi nyawa orang-orang yang wajib dijaga seperti umat Islam, kafir dzimmi, kafir mustaman, memerintahkan kebenaran (amar máruf), dan lain-lain. ${ }^{6}$

Sedangkan yang bisa dinamakan mujahid yang mendapat kategori syahid (mati syahid) dunia-akhirat (orang yang menjadi saksi penegakan agama Allah di dunia dan akhirat, baik di sisi manusia maupun di sisi Allah), yaitu orang yang mati dalam medan laga melawan orang kafir demi keagungan agama Allah, bukan karena tujuan duniawi, tapi murni karena Allah. Kategori ketiga ini tidak dimandikan dan tidak dishalati, tapi langsung dikafani dan dikubur. ${ }^{7}$ Doktrin mujahid ini berlaku di daerah perang, bukan daerah damai seperti di Indonesia. Doktrin mujahid ini ada di Negara-negara Islam yang ditindas oleh nonmuslim, seperti di Palestina. Kaum muslimin di Palestina yang mengalami tekanan politik dan ekonomi dari dunia internasional yang tidak pernah tegas mengutuk Israel sebagai biang kerok kolonialisme. Meskipun demikian, bom bunuh diri terbukti tidak efektif menghentikan tindakan sadis Israel. Oleh karena itu, dalam konteks ini, jalur diplomasi, penguatan teknologi persenjataan, ekonomi, dan soliditas internal adalah langkah prioritas yang harus dioptimalkan.

\section{Akar Ideologi Kelompok Radikal}

Akar ideologi kelompok radikal adalah pola pemahaman tekstual terhadap al-Qur'an dan hadis dan anti dialog. Selain itu, kelompok radikal mempunyai fanatisme absolut terhadap imam-imam yang diikuti. Pemahaman yang berbeda dan bertentangan dengan pendapat imam mereka dianggap sesat. Akar kelompok ini bisa ditelusuri dari sejarah permusuhan Barat dan Islam. Kelompok ini menolak sekularisasi, westernisasi, dan modernisasi. Kelompok ini berorientasi politik dengan bergerak di bawah tanah dengan basis jamaah yang eksklusif. Mereka menginginkan kepemimpinan politik universal. Mereka dikenal dengan kaum salafi karena ingin menerapkan Islam seperti kalangan salaf (terdahulu) dalam mengamalkan ajaran Islam. Mereka menggunakan metode salafi dalam memahami Islam dengan ciri utamanya, yaitu pendekatan tekstualis. Mereka menolak realitas sekarang dan ingin mengubahnya sesuai dengan doktrin masa lalu. Secara simbolis, kelompok ini dapat dilihat dari wanita berjilbab yang menggunakan cadar (penutup wajah) dan untuk pria berbaju putih dengan celana panjang di atas mata kaki dan berjanggut panjang. ${ }^{8}$

Kelompok ini merupakan kelanjutan dan kesinambungan dari gerakan pemurnian Islam pada masa Ibn Hanbal, Ibn Taimiyyah dan Ibn Abdul Wahhab dan reaksi terhadap tantangan

6 Abu Bakar Syataha, tt., I'anatut Thalibin ala Fathil Muin, Jakarta (Daru Ihyail Kutub al-Arabiyyah), Juz, 4, hlm. 180-184.

7 Imam Taqiyyuddin Abu Bakar bin Muhammad al-Husaini, tt., Kifayah al-Akhyar, Jakarta: Daru Ihyail Kutub al-Arabiyyah, juz 1, hlm. 164-165.

8 As'ad Said Ali, 2013, Ideologi Gerakan Pasca Reformasi, Gerakan-Gerakan Sosial-Politik Dalam Tinjauan Ideologis, Jakarta: LP3ES, cet. 2, hlm. 70-71 
dunia modern. Kelompok ini bergulat pada pemikiran dan gerakan, seperti jaringan Ikhwanul Muslimin, Hizbut Tahrir Indonesia, Majlis Mujahidin Indonesia, Front Pembela Islam, Laskar Jihad, dan lain-lain yang bermain di level praktis. Mereka berambisi menghadirkan Islam otentik dan kaffah yang harus diberlakukan di seluruh dunia. Proyek otentifikasi dan universalisme Islam mengandaikan pandangan dunia yang diinspirasi oleh Islam sebagai kerangka normative yang transenden, baku, tak berubah, dan kekal yang dibangun oleh sendi-sendi dasar yang ada dalam teks kitab suci dan ajaran Nabi di Mekah dan Madinah sebagai basis geografis Islam. Islam menurut mereka dipandang sebagai agama yang tuntas dan paripurna di masa lalu dan tidak boleh mengalami kontekstualisasi dan modifikasi. ${ }^{9}$

Otentifikasi meniscayakan ketundukan kepada teks Al-Qur'an, hadis dan pengalaman masa lalu dalam bentuk tekstualnya dalam lapangan sosial politik. Tindakan sosial politik Nabi dan sahabat dianggap sebagai contoh final yang harus ditiru umat Islam di manapun dan kapanpun. Islam kaffah yang diperjuangkan dimaknai sebagai realisasi pengislaman seluruh system hidup, mulai dari ekonomi, masyarakat, Negara lengkap dengan symbol dan bentuknya. Inilah yang melahirkan gerakan politik identitas Islam yang digagas oleh madzhab Wahhabi, Maududian dan Quthbian yang dianggap pemeluknya sebagai satu-satunya kebenaran. Inilah Islam otentik yang harus diterapkan umat Islam seluruh dunia. ${ }^{10}$

Salah satu doktrin utama yang diyakini kelompok radikal adalah jihad menegakkan agama Allah dengan jiwa dan raga. Dalam doktrin jihad ini, praktek bunuh diri diperbolehkan, bahkan dianjurkan jika bertujuan menegakkan agama Allah. Secara terminologis, bunuh diri adalah melakukan hal-hal yang membuat nyawa melayang, seperti minum racun, memasang bom di badannya, menusuk dirinya dengan benda-benda tajam, masuk ke dalam sumur, menenggelamkan diri ke laut, danau, dan sejenisnya, apapun motif perbuatannya, apakah karena prustasi atau ingin mati syahid (istisyhad). ${ }^{11}$

Fenomena bunuh diri ini menjadi kajian menarik sejak lama. Neokolonialisme Israel di Jalur Ghaza Palestina dan AS di Iraq dan Afghanistan melahirkan trend bunuh diri atas nama 'istisyhad' (upaya melakukan mati syahid). Ini menjadi solusi instant dan jangka pendek dari ketidakberdayaan melawan hegemoni, dominasi, dan otoritarianisme neokolonialis dan neoimperialis Israel dan AS, dua Negara yang selalu kooperatif dalam konteks menindas Negaranegara muslim. Apakah opsi bunuh diri dengan alasan 'istisyhad' dijadikan solusi strategis dan efektif kaum muslim di Palestina di tengah ketidakberdayaan melawan musuh. Realitas ini sangat ironis, karena secara faktual, hegemoni kolonialis dan imperialis terlalu tangguh jika hanya dilawan hanya dengan bom bunuh diri yang tidak banyak berpengaruh terhadap gerakan musuh.

9 M. Imdadun Rahmat, dkk, 2003, Islam Pribumi, Menolak Arabisme, Mencari Islam Indonesia, Jakarta: Jurnal Tashwirul Afkar PP Lakpesdam, Edisi No. 14, hlm. 13-14

10 M. Imdadun Rahmat, dkk, 2003, Islam Pribumi, Menolak Arabisme, Mencari Islam Indonesia, Jakarta: Jurnal Tashwirul Afkar PP Lakpesdam, Edisi No. 14, hlm. 14

11 Akh. Fauzi Aseri, 2002, Euthanasia, Suatu Tinjauan dari Segi Kedokteran, Hukum Pidana, dan Hukum Islam, dalam Problematika Hukum Islam Kontemporer, Editor : Dr. H. Chuzaimah T. Yanggo dan HA. Hafiz Anshary AZ., MA., Jakarta: Pustaka Firdaus dan LSIK, cet. 3, hlm. 64 


\section{Larangan Bunuh Diri}

Al-Qur'an dengan tegas melarang bunuh diri yang dijelaskan dalam banyak tempat. Pertama, dalam QS. An-Nisa’ 29: Hai orang-orang yang beriman, janganlah kamu saling memakan harta sesamamu dengan jalan yang batil, kecuali dengan jalan perniagaan yang berlaku dengan suka sama-suka di antara kamu. dan janganlah kamu membunuh dirimu; Sesungguhnya Allah adalah Maha Penyayang kepadamu. ${ }^{12}$ Kedua, dalam QS. al-Isra' 33: Dan janganlah kamu membunuh jiwa yang diharamkan Allah (membunuhnya), melainkan dengan suatu (alasan) yang benar. dan barangsiapa dibunuh secara zalim, Maka Sesungguhnya kami Telah memberi kekuasaan kepada ahli warisnya, tetapi janganlah ahli waris itu melampaui batas dalam membunuh. Sesungguhnya ia adalah orang yang mendapat pertolongan. ${ }^{13}$ Ketiga, dalam QS. al-Maidah 32: Oleh Karena itu kami tetapkan (suatu hukum) bagi Bani Israil, bahwa: barangsiapa yang membunuh seorang manusia, bukan Karena orang itu (membunuh) orang lain, atau bukan Karena membuat kerusakan dimuka bumi, Maka seakan-akan dia Telah membunuh manusia seluruhnya. dan barangsiapa yang memelihara kehidupan seorang manusia, Maka seolah-olah dia Telah memelihara kehidupan manusia semuanya. dan Sesungguhnya Telah datang kepada mereka rasul-rasul kami dengan (membawa) keterangan-keterangan yang jelas, Kemudian banyak diantara mereka sesudah itu sungguh-sungguh melampaui batas dalam berbuat kerusakan di muka bumi.

Dalam memahami ayat al-Qur'an di atas, para ulama menjelaskan maksudnya sebagai berikut. Pertama, Allah melarang membunuh diri sendiri dan orang lain, karena asas yang dibangun Islam adalah persatuan umat, saling membantu dan menolong satu dengan yang lain, seperti dalam sebuah hadits : al-muminuna ka al-nafsi al-wahidah' orang-orang mukmin seperti satu jiwa. Dan membunuh orang lain akan menyebabkan dirinya dibunuh secara qishas atau pembalasan, jadi dia seperti membunuh dirinya sendiri. ${ }^{14}$

Kedua, karena membunuh orang lain dilarang, maka membunuh diri sendiri dalam hal ini bunuh diri (intihar) lebih berat salahnya dan lebih ngeri dosanya yang tidak sah apabila lahir dari orang yang beriman. Karena itu al-Qur'an tidak melarang kita secara jelas. ${ }^{15}$ Ketiga, dalam Tafsir Khozin dijelaskan sebuah haditsyang diriwayatkanAbuHurairah, NabiMuhammadSaw. bersabda:

12 QS. An-Nisa' 29: Anfusakum: sebagian kamu kepada sebagian yang lain. Baca dalam Syekh al-Maraghi, 2006, Tafsir al-Maraghi, Beirut Libanon: Darul Fikri, Juz 2, hlm. 137 dan Muhammad Mahmud Hijazi, Tafsir Wadlih, Beirut Libanon: Darul Fikri, juz 1-10, hlm. 364

13 Bil haqqi: dengan tujuan kebenaran, yaitu salah satu tiga hal: kufur setelah iman (murtad), zina muhshon (status sudah nikah), dan membunuh orang mukmin yang baik dengan sengaja. Lihat dalam Syekh al-Maraghi, 2006, Tafsir al-Maraghi, Beirut Libanon: Darul Fikri, Juz 5, hlm. 213

14 Syekh al-Maraghi, 2006, Tafsir al-Maraghi, Beirut Libanon: Darul Fikri, juz 2, hlm. 137

15 Muhammad Mahmud Hijazi, Tafsir Wadlih, Beirut Libanon: Darul Fikri, Juz 1-10, H. 366. untuk lebih detail baca juga di Abu Ja'far Muhmmad bin Hasan al-Thusi, al-Tibyan fi Tafsir al-Qur'an, Beirut Libanon : Daru Ihyai al-Turats al-Arabi, Jilid 3, H. 179-180, Imam Muhammad Thohir bin 'Asyur, Tafsir al-Tahrir wa al-Tanwir, Tunisia : Darul Jamahiriyyah li al-Nasyr wa al-Tazi' wa al-I'lan, Juz 3-5, H. 25, Abu al-Hasan Ali bin Muhammad bin Habib al-Mawardi al-Bashri, al-Nukat wa al-Uyun Tafsir al-Mawardi, Beirut Libanon: Muassasah al-Kutub al-Tsaqafiyyah dan Darul Kutub al-Ilmiyyah, jilid 1, hlm. 475 


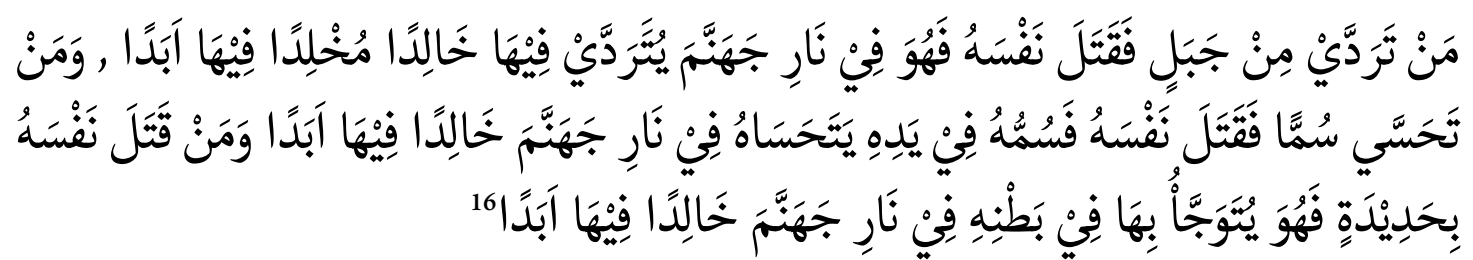

Artinya: "Barang siapa jatuh dari gunung, kemudian membunuh dirinya sendiri, maka dia berada di neraka Jahannam, ia dijatuhkan ke dalamnya abadi selamanya di dalamnya, barang siapa memakan racun, kemudian membunuh dirinya, maka racun yang ada dalam tangannya yang ia makan akan berada di neraka Jahannam abadi selamnya di dalamnya, dan barang siapa membunuh dirinya sendiri dengan potongan besi, maka perutnya akan dipukuli dengannya di neraka Jahannam abadi selamanya di dalamnya."

Hadis ini menguatkan larangan bunuh diri. Ada empat pendapat: Pertama, janganlah sebagian kamu membunuh sebagian yang lain karena kamu satu agama bagaikana satu jiwa (Hasan, Atha', Suda, dan Jubai). Kedua, janganlah manusia membunuh dirinya sendiri dalam keadaan emosi atau gelisah (Abu al-Qosim al-Bulkhi). Ketiga, janganlah kamu semua membunuh dirimu sendiri dengan melakukan hal-hal dosa, permusuhan dalam memakan harta haram dengan bathil dan kemaksiatan lainnya yang kamu akan mendapatkan siksa. Keempat, jangan membahayakan dirimu dalam perang, maka kamu akan membunuh orang yang kamu mampu atasnya (Abu Abdillah). ${ }^{17}$ Dalam ayat lain dijelaskan bahwa haramnya membunuh disebabkan tiga faktor: Pertama, Merusak (ifsad) sesuai firman Allah QS. al-A'raf 56 : Dan janganlah kamu membuat kerusakan di muka bumi. Kedua, membahayakan (dharar). Asal hukum membahayakan adalah haram, sesuai firman Allah QS. al-Baqarah 185: Allah menghendaki kemudahan bagimu, dan tidak menghendaki kesukaran bagimu. Dan hadis Nabi: لَا ضَرَرَ وَلَا ضِرَارَ (tidak boleh ada bahaya dan tidak boleh membahayakan). ketiga, Jika membunuh diperbolehkan, maka hilangnya makhluk yang namanya manusia, karena yang kuat merusak yang lemah. Jika ini terjadi maka instabilitas sosial terjadi di mana-mana dan tidak ada mekanisme jaminan sosial yang kondusif dalam kehidupan. ${ }^{18}$

Islam juga melarang membunuh diri sendiri dalam keadaan emosi atau gelisah (cemas). Ini yang dinamakan bunuh diri (intihar). Sesuai sabda Nabi Muhammad Saw. :

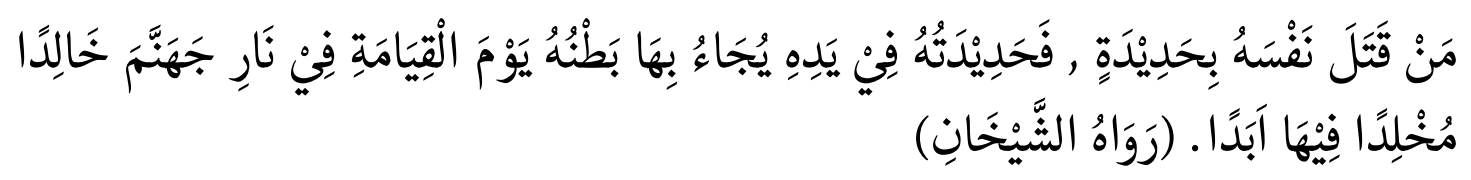

Artinya: Barang siapa membunuh dirinya sendiri dengan potongan besi, maka potongan besinya yang ada di tangannya akan dibenamkan dalam perutnya di hari kiamat di neraka Jahannam, ia di dalamnya abadi selamanya (HR. Syaikhani).

16 Sulaiman bin Umar al-Uaili al-Syafi'I al-Syahir bi al-Jamal, 1996, al-Futuhatul Ilahiyyah Bi Taudlihil Jalalain li al-Daqoiq al-Khofiyyah, Beirut Libanon: Darul Kutub al-Ilmiyyah, juz 2, hlm. 42

17 Abu Ali al-Fadhl bin Hasan al-Thobrasi, t.th., Majma' al-Bayan fi Tafsir al-Qur'an, Beirut Libanon: Mafafturat Daru Maktabah al-hayat, jilid 2, hlm. 81-82

18 Syekh al-Maraghi, 2006, Tafsir al-Maraghi, Beirut Libanon: Darul Fikri, juz 5, hlm. 214 
Namun mayoritas mufassirin sepakat bahwa maknanya adalah sebagian kamu jangan membunuh sebagian yang lain. Namun tidak ada yang melarang kalau ayat di atas ditafsirkan dengan larangan membunuh diri sendiri dan membunuh orang lain dan semua hal yang menjurus kepada kematian, seperti mengkonsumsi hal-hal yang membahayakan, racun yang membahayakan, dan mempertaruhkan dirinya (mujazafah) dalam hal-hal yang merusak. ${ }^{19}$

Secara holistik, pandangan al-Qur'an tentang bunuh diri adalah: Pertama, barang siapa membunuh seseorang tanpa sebab kerusakan di bumi yang mengganggu keamanan, ketenangan, menghancurkan tanaman dan keturunan sebagaimana dilakukan kawanan perampok yang membawa pedang yang disiapkan untuk membunuh manusia, merampas harta atau merusak sesuatu pada Negara yang bertugas menegakkan aturan-aturan Allah, maka barang siapa melakukan sesuatu dari semua itu, maka ia seperti membunuh manusia seluruhnya, karena satu orang adalah sampel orang lain. Barang siapa menghalalkan darahnya tanpa jalan yang dibenarkan, maka ia sama dengan menghalalkan darah semua orang. ${ }^{20}$

Kedua, kita wajib menjaga jiwa manusia seperti menjaga diri kita sendiri. Adapun menjaga diri sendiri justru wajib secara lebih utama, maka tidak diperbolehkan dalam keadaan apapun membunuh dirinya sendiri seperti menyiksa diri supaya selamat dari kesusahan dan beban hidup. Jika ujian itu terasa berat bagi orang mukmin, maka dia sabar, menyerahkan diri kepada Allah dan tidak putus harapan pada kegembiraan Allah (faraj ilahiyyah). Maka orang yang menyiksa diri (bunuh diri) banyak terjadi bagi orang yang imannya lemah dan saat kekafiran merajalela. Sedangkan salah satu fungsi iman adalah menolak musibah dan kotoran, orang yang beriman tidak merasa sakit dengan beban hidup sebagaimana orang kafir merasakannya, maka tidak layak ia menyiksa dirinya, sehingga harus dilarang Allah dengan jelas. ${ }^{21}$

Ketiga, larangan membunuh secara umum, tidak hanya khusus Bani Israil. Larangan membunuh ini kecuali pada tiga hal : kufur setelah iman (murtad), zina setelah ihshan (menjaga diri), dan membunuh orang secara aniaya atau sengaja. Sedangkan pengertian 'fasad' adalah syirik (menyekutukan Allah), ada yang berpendapat, merampok. Dan membunuh manusia sama dengan membunuh semua manusia, dan menghidupkan manusia sama dengan menghidupnya semua manusia. ${ }^{22}$

Dari sini diketahui bahwa jiwa orang yang dibunuh bukan miliknya, tapi ia milik masyarakat yang hidup bersamanya. Maka, barang siapa menyalahi jiwa, walau dirinya sendiri dengan bunuh diri, maka dia berhak mendapat siksa Allah yang berat di hari kiamat, dan barang siapa menghidupnya sebuah jiwa, sengan sebab apapun, maka ia seperti menghidupkan manusia

19 Wahbah al-Zuhaili, 1998, al-Tafsir al-Munir fi al-Aqidah wa al-Syari'ah wa al-Manhaj, Beirut Libanon: Darul Fikri, juz, 5-6, hlm. 32

20 al-Maraghi, Tafsir al-Maraghi, Beirut Libanon : Darul Fikri, 2006, Juz 2, H. 290 dan Muhammad Mahmud Hijazi, Tafsir Wadlih, Beirut Libanon: Darul Fikri, juz 1-10, h. 506

21 Muhammad Rasyid Ridlo, 1999, Tafsir Manar, Beirut Libanon: Darul Kutub al-Ilmiyyah, juz 5, hlm. 37

22 Abu Abdillah Muhammad bin Ahmad al-Anshari al-Qurtubi, 2002, al-Jami' li Ahkam al-Qur'an, Kairo: Darul Hadits, Juz 3, H. 508 \& Wahbah al-Zuhaili, 1998, al-Tafsir al-Munir fi al-Aqidah wa al-Syariah wa alManhaj, Beirut Libanon: Darul Fikri, juz 5-6, hlm. 159-160 
seluruhnya, karena setiap jiwa adalah anggota masyarakat ('udlwu al-mujtama'). ${ }^{23}$ Solidaritas dan kohesivitas sosial sangat terlihat dalam ayat ini, sehingga semua manusia harus dilindungi keamanannya.

\section{E. Islam Menjamin Keamanan Manusia}

Islam melindungi keamanan manusia tanpa melihat agamanya. Piagam Madinah membuktikan hal tersebut. Kajian panjang lebar di atas juga meneguhkan hal ini. Kajian tentang larangan bunuh diri di atas menyimpulkan beberapa hal: Pertama, penghargaan besar Islam dalam masalah jiwa (nafs) manusia. Darah adalah sesuatu yang dijamin keamanannya dalam Islam. Jiwa (nafs) termasuk lima hal yang masuk kategori kulliyatul khoms (lima hak-hak asasi universal), yaitu menjaga agama (din), jiwa (nafs), harta (mal), akal (aql), keturunan (nasl) dan harga diri ('irdl). Hal ini secara tersirat ada dalam firman Allah QS. al-Mumtahanah 12: Hai Nabi, apabila datang kepadamu perempuan-perempuan yang beriman untuk mengadakan janji setia, bahwa mereka tiada akan menyekutukan Allah, tidak akan mencuri, tidak akan berzina, tidak akan membunuh anak-anaknya, tidak akan berbuat dusta yang mereka ada-adakan antara tangan dan kaki mereka dan tidak akan mendurhakaimu dalam urusan yang baik, Maka terimalah janji setia mereka dan mohonkanlah ampunan kepada Allah untuk mereka. Sesungguhnya Allah Maha Pengampun lagi Maha Penyayang. ${ }^{24}$

Lima hal di atas dijamin betul dalam Islam, sehingga barang siapa mencederai lima hal ini, baginya jinayat (proses pidana). ${ }^{25}$ Lima hal ini popular dengan maslahah dharuriyah. hifdzu aldin meniscayakan solidaritas, soliditas, kohesivitas, dan toleransi antar umat beragama, hifdzu al-nafs meniscayakan progresifitas dan akuntabilitas aparat keamanan dalam memberikan rasa aman bagi rakyat, menjaga dari hal-hal yang berpotensi menyebabkan konflik, konfrontasi, dan agresi yang selalu memakan korban jiwa, hifdzu al-aqli meniscayakan pemerintah untuk mengembangkan dunia pendidikan agar menjadi dinamis, kompetitif, kreatif, produktif, dan progresif ditengah iklim kompetisi global yang ketat sekarang ini, hifdzu al-mal meniscayakan pemerintah untuk mengentaskan kemiskinan, pengangguran, mengeliminir angka kriminalitas, dengan program-program riil, sistematis, dan berkelanjutan, hifdzu al-nasli wa al-ardl meniscayakan pemerintah untuk mendidik rakyatnya, khususnya generasi muda agar menjauhi segala tindakan amoral dan asusila seperti free sex, pemerkosaan, dan sejenisnya, mendorong rakyatnya untuk menciptakan keluarga sakinah, dan menciptakan suasana interaksi sosial yang penuh kedamaian, kebersamaan, kekompakan, dan penghormatan yang tinggi terhadap hakhak sesama.

Kedua, bentuk larangan (nahi) memakai kata 'la' kebanyakan menunjukkan hukum haram

23 Muhammad Mahmud Hijazi, Tafsir Wadlih, Beirut Libanon: Darul Fikri, Juz 1-10, hlm. 506

24 Muhammad Rasyid Ridlo, 1999, Tafsir Manar, Beirut Libanon: Darul Kutub al-Ilmiyyah, juz 5, hlm. 36 \& Wahbah Az-Zuhaili, 2005, Ushul al-Fighi al-Islami, Beirut Libanon: Dar al-Fikri, cet. 14, juz 2, hlm. 310-311

25 Ibrahim al-Bajuri, Hasyiyah al-Bajuri, Surabaya: Maktabah Shohabah Ilmu, tt. juz 2, hlm. 199-200 dan Abu Bakar Syatha, I'anah al-Tholibin ala Hilli Alfadhi Fathil Mu'in, Jakarta: Daru Ihyail Kutub al-Arabiyyah Indonesia, tt. Juz 4, hlm. 109-110 
(li al-tahrim), kecuali ada sesuatu yang meniadakan sehingga bisa menunjukkan hukum makruh, mengarahkan, berdo'a, menjelaskan akibat, menyedikitkan, meremehkan, dan putus asa. Nahi yang bermakna haram menunjukkan bahwa obyeknya rusak (fasad). ${ }^{26}$ Dalam konteks ini, bunuh diri atau membunuh orang lain hukumnya haram kecuali tiga perkara yang dijelaskan dalam sebuah hadits:

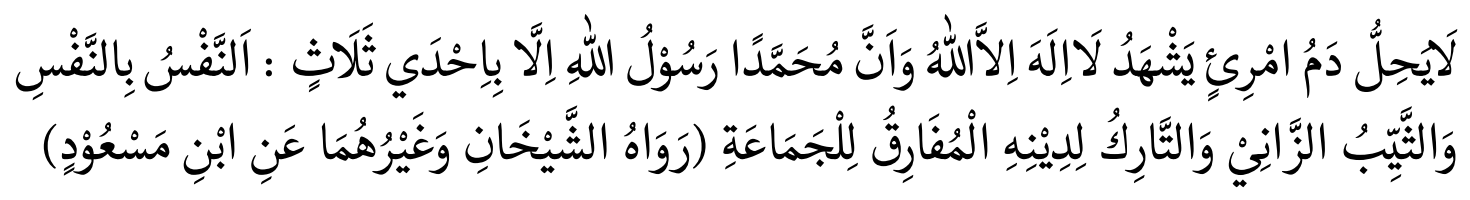

Artinya: Tidak halal darah seseorang yang bersaksi bahwa tiada tuhan selain Allah dan sesungguhnya Nabi Muhammad adalah utusan Allah kecuali dengan salah satu tiga hal, membunuh seseorang, janda yang zina, dan orang yang meninggalkan agamanya (murtad) yang berpisah dari golongan (umat Islam) (HR. Bukhari-Muslim dan lainnya dari sahabat Ibnu Mas'ud). ${ }^{27}$

Ketiga, bunuh diri hukumnya haram mutlak, karena ia tidak menghormati nyawa yang diberikan Allah Swt., bukti bahwa ia tidak bersyukur kepada Allah atas nikmat hidup yang diberikan kepadanya, ia merasa bina menghidupkan dan mematikan sendiri, sedangkan hal itu adalah hak prerogative Allah, merasa bahwa setelah kematian tidak ada pertanggung jawaban amal, dan ironisnya ia akan menerima siksa yang sangat pedih, tidak seimbang dengan jalan pintas (bunuh diri) yang dilakukan. Hadits ini jelas melarang kita mengharapkan kematian karena musibah, bencana, rasa takut dan lain-lain yang terasa berat dipikul, masalah seberat apapun diserahkan kepada Allah, dan pata titik klimaks, diperbolehkan berdo'a sebagaimana di atas. ${ }^{28}$ Dalam hadits di atas juga dijelaskan bahwa mengharap mati yang diperbolehkan antara lain : takut terkena fitnah dalam agama, ingin mendapatkan mati syahid, dan takut harga dirinya rusak sebagaimana kisah Maryam. ${ }^{29}$

Walaupun begitu, tujuan dan instrumentnya tidak boleh bertentangan. Keduanya harus ada dalam koridor hukum yang benar. Misalnya, karena ingin mati syahid, kemudian bom bunuh diri untuk menghancurkan musuh, dimana perbuatan ini dilarang Allah, atau mempercepat kematian demi keselamatan agamanya. Justu dengan perbuatan ini, tujuannya tidak tercapai, artinya dia tidak jadi mati syahid dan ia semakin sengsara di alam barzakh dan hari kiamat. Tujuan yang baik tidak bisa menghalakan sesuatu yang dilarang Allah. Dalam konteks ini, ingat firman Allah QS. al-Baqarah 195: Dan belanjakanlah (harta bendamu) di jalan Allah, dan janganlah kamu menjatuhkan dirimu sendiri ke dalam kebinasaan, dan berbuat baiklah, karena sesungguhnya Allah menyukai orang-orang yang berbuat baik.

26 Al-Jalal Syamsuddin Muhammad bin Ahmad al-Mahalli, Hasyiyah al-Allamah al-Bannani ala matni Jam’i al-Jawami', Jakarta: Daru Ihyail Kutub al-Arabiyyah Indonesia, tt. Juz 2, hlm. 390-398

27 al-Maraghi, 2006, Tafsir al-Maraghi, Beirut Libanon: Darul Fikri, juz 5, hlm. 213

28 Hasan Sulaiman al-Nawawi dan Alawi Abbas al-Maliki, 2004, Ibanah al-Ahkam Syarhu Bulughil Maram, Beirut Libanon: Darul Fikri, juz 2, hlm. 147-149

29 Hasan Sulaiman al-Nawawi dan Alawi Abbas al-Maliki, 2004, Ibanah al-Ahkam Syarhu Bulughil Maram, Beirut Libanon: Darul Fikri, juz 2, hlm. 147-149 


\section{F. Memperburuk Citra Islam}

Bunuh diri memperburuk citra umat Islam dunia dan tidak menyelesaikan masalah. Palestina sampai sekarang masih belum keluar dari intimidasi dan hegemoni Israel, meskipun bom bunuh diri terus dilakukan. Dalam konteks ini, diplomasi internasional, konsolidasi internal, dan soliditas team work terbukti menjadi solusi efektif jangka panjang yang menjanjikan perubahan signifikan dari pada bunuh diri yang sangat kontraproduktif. Sekarang ini, jihad dalam bentuk perang sudah tidak efektif dan hanya memunculkan banyak kematian yang tidak berguna, sementara tujuannya sulit tercapai. Kedigdayaan musuh tidak berkurang sedikitpun dengan fenomena 'bunuh diri' karena mereka menguasai iptek dan diplomasi internasional. Jihad kontemporer dalam bentuk pendalaman spiritual, pengembangan kualitas pendidikan, penguatan basis ekonomi nasional, kaderisasi, penguasaan iptek, dan internalisasi semangat berjuang yang diinternalisir secara maksimal lebih efektif, bermanfaat dalam jangka panjang, dan mampu membawa perubahan dahsyat dan kokoh, sehingga tidak mudah dirobohkan.

Dalam konteks ini, kelompok radikalis tidak akan mampu menyingkirkan Amerika Serikat dan Israel kalau strategi perjuangannya mengandalkan 'ancaman kecil'. Amerika Serikat dan Israel takut dan segan menghadapi Iran yang kualitas pendidikan, ekonomi nasional, penguasaan iptek, dan soliditas nasionalnya tinggi dan mampu menyaingi mereka. Inilah yang harus direnungkan secara mendalam, sehingga solusi instant dalam bentuk bunuh diri secepatnya dihentikan dan secara kolektif mempercepat jihad kontemporer. Kompetisi utama sekarang ini di bidang pengetahuan dan teknologi yang menentukan segala bidang, termasuk pendidikan, ekonomi, dan politik. Jihad yang sebenarnya adalah jihad di bidang ini, bukan jihad dengan membunuh nyawa diri dan orang lain yang bertentangan dengan syariat Islam.

\section{G. Rekonstruksi Teologi Radikalisme}

Dalam menghadapi kelompok radikalis dengan teologi yang ekstrim, dibutuhkan beberapa langkah untuk melakukan rekonstruksi.

Pertama, mengkaji ayat-ayat dan hadis-hadis yang menjadi dasar dengan multi pendekatan, baik tekstual, maupun sosiologis, historis, antropologis, dan politis. Multi pendekatan ini akan menggambarkan makna teks secara komprehensif. Kekayaan tafsir dan syarah hadis menunjukkan kekayaan pemikiran Islam. Kedua, membuat rumusan yang jelas mana ayat dan hadis yang pasti-absolut (qath'iyyat-muhkamat) dan mana ayat dan hadis yang prediktif-asumtif (dhanniyyat-mutasyabihat). Jika sudah ditemukan, maka pegangan utamanya adalah ayat-ayat yang pasti-absolut karena menjadi rujukan kapanpun dan di manapun. Sedangkan ayat dan hadis yang prediktif-asumtif menjadi potret historis pada masa Nabi sebagai respons atas persoalan yang sedang terjadi. Dalam konteks ini, ayat-ayat yang mengandung ajaran universal, seperti kemanusiaan, keadilan, hak asasi manusia, perdamaian, solidaritas sosial, dan kesetaraan harus menjadi dalil yang qath'iyyat-muhkamat yang sifatnya eternal yang harus mewarnai seluruh ajaran Islam yang mengarah kepada tercapainya maqasidus syariah (tujuan syariat Islam), yaitu menjaga agama, jiwa, akal, harta, dan keturunan. Menurut Abdurrahman Wahid, persamaan 
derajat di muka hukum, penjagaan hak-hak kelompok lemah dan kekurangan, pembatasan wewenang para pemegang kekuasaan, dan perlindungan terhadap warga masyarakat dari kezaliman dan kesewenang-wenangan adalah bukti universalisme Islam dan kosmopolitanisme peradaban Islam. ${ }^{30}$ Adapun dalil yang mengandung ajakan berperang dan sejenisnya dijadikan sebagai dalil dhanniyyat-mutasyabihatyang sifatnya temporer dan kasuistis. Doktrin ini dilakukan dalam situasi darurat karena sifatnya defensif dan dalam rangka menjaga agama, jiwa, harta, akal, keturunan dan harga diri. Menjaga lima hak dasar ini adalah kemaslahatan dan segala sesuatu yang mengganggu lima hak dasar ini adalah kerusakan yang harus dihindari.

Ketiga, mengapresiasi pluralitas kebudayaan Indonesia dengan latar sejarah yang beragam untuk menemukan kearifan local (local wisdom) yang menjadi kekayaan budaya bangsa Indonesia dari Sabang sampai Merauke. Keempat, belajar dengan bijaksana atas kesuksesan dakwah Walisongo yang menggunakan pendekatan kebudayaan. Walisongo tidak memberikan stigma negatif budaya yang berkembang di masyarakat, tapi membimbing, mengarahkan, dan memberikan substansi ajaran agama sehingga budaya yang ada di masyarakat sesuai dengan nilai-nilai Islam. Lebih dari itu, kekayaan budaya yang ada di masyarakat dijadikan media dakwah Islam, seperti Sunan Kalijaga yang menjadikan wayang sebagai media dakwah yang efektif. Masyarakat berduyun-duyun menghadiri pentas wayang Sunan Kalijaga dan secara tersirat Sunan Kalijaga memasukkan materi agama dalam cerita wayang. Kelima, merumuskan teologi multikulturalisme Islam yang berisi nilai-nilai persaudaraan, kebersamaan, toleransi, dan keadilan. Nilai-nilai ini harus termanifestasi dalam kehidupan sosial umat Islam. Contoh menarik nilai ini adalah Sunan Kudus yang mengharamkan menyembelih sapi sebagai bentuk penghormatan kepada agama lain. Dakwah Sunan Kudus ini kemudian melahirkan simpati publik secara luas dan menyebabkan Islam diterima dan berkembang pesat di Kudus.

\section{H. Menuju Islam Rahmatan Lil-Alamin}

Rekonstruksi teologi radikal di atas dalam rangka meneguhkan Islam yang rahmatan lilalamin, yaitu Islam yang menjadi rahmat bagi seluruh alam. Tidak mungkin Islam tampil sebagai rahmat jika doktrin yang dikaji, dikembangkan, dan dipraktekkan adalah doktrin kebencian, permusuhan, dan pembunuhan yang bertentangan dengan hak asasi manusia. Sejarah Islam era Nabi dan sahabat yang berisi peperangan dimaknai secara metode devensif. Artinya, Islam dan umat Islam dalam kondisi terdesak sehingga mereka memberikan perlawanan kepada nonmuslim yang ingin menghancurkan Islam dan umatnya.

Jika Islam terlibat dalam peperangan, maka perempuan dan anak-anak dijaga dan dilindungi. Laki-laki nonmuslim jika menyerah dalam peperangan diberikan jaminan keamanan, seperti yang dipraktekkan Nabi Muhammad ketika fath Makkah (pembebasan kota Makkah). Ketika nonmuslim mau hidup berdampingan secara rukun dan damai dengan muslim, maka Nabi menjaminan keamanan dan keselamatannya. Hal inilah yang dipraktekkan Nabi dengan membuat Piagam Madinah yang menjadi kesepakatan politik antara umat Islam dan nonmuslim

30 Abdurrahman Wahid, 2007, Universalisme Islam dan Kosmopolitanisme Peradaban Islam, dalam buku Islam Universal, Yogyakarta: Pustaka Pelajar, hlm. 1 
untuk bersama-sama menjaga keamanan, keselamatan, dan kedamaian dan menjauhi segala macam tindakan yang merusak dan mengancam keselamatan kolektif. Teladan agung Nabi ini seharusnya menginspirasi umat Islam era sekarang supaya hidup rukun dengan nonmuslim. Di era sekarang ini, kompetisi terbuka ada di bidang pendidikan dan ekonomi. Maka, energi umat Islam tidak boleh dikuras dalam perang fisik, tapi harus dicurahkan secara optimal untuk mengentaskan kemiskinan dan kebodohan umat supaya umat Islam tampil sebagai umat terbaik di muka bumi dengan prestasi-prestasi besar. Dengan inilah, Islam mampu menampakkan prestasi besarnya.

\section{Penutup}

Manusia harus menyadari bahwa hidup dalam keadaan apapun adalah kesempatan untuk menambah bekal menghadapi proses kiamat yang panjang dan mengerikan. Hanya mereka yang bekal amal salehnya banyak tulus karena Allah yang selamat. Kematian tidak bisa dimajukan dan diakhirkan, mencoba bunuh diri atau minum racun kalau ajalnya belum tiba tidak akan mati. Oleh sebab itu langkah terbaik adalah memperbanyak taqwa dan meminimalisir dosa. Tawakkal disertai dengan usaha (ikhtiyar) maksimal adalah langkah terbaik dan dalam keadaan apapun, amal saleh tetap bisa dilakukan. Kesabaran, ketabahan, kegigihan, dan keyakinan akan pertolongan Allah adalah obat mujarab dari kesedihan dan ujian yang menimpa manusia.

Islam adalah agama yang membawa misi utama rahmatan lil-alamin yang cinta damai, toleran, moderat, dan anti terhadap kekerasan, ancaman, dan menghalalkan segala cara. Baginda Nabi Besar Muhammad SAW. membuktikan diri sebagai aktor yang berjuang menegakkan nilianilai kemanusiaan, keadilan, kedamaian, toleransi, solidaritas universal, hak asasi manusia, dan kebersamaan. Ketika Nabi mempimpin masyarakat Madinah yang plural, maka aspek ibadah dan sosial dibedakan. Aspek ibadah menjadi urusan privat masing-masing agama, sedangkan aspek sosial menjadi wilayah terbuka yang satu dengan yang lain harus saling melengkapi dan tolong menolong.

Inilah Islam yang benar yang diperjuangkan Nabi Muhammad SAW. Radikalisme, ekstrimisme, dan terorisme yang mengatasnamakan Islam adalah pembodohan publik secara kejam karena menghina Islam dengan tindakan yang bertentangan dengan Islam. Oleh sebab itu, kelompok radikal ini harus dilawan supaya tidak berkembang. Kader-kader muda Islam harus diberi pemahaman yang benar tentang jihad sehingga tidak terlibat dalam jihad yang identik dengan bom bunuh diri yang mengancam keselamatan orang lain, bahkan kepada mereka yang tidak bersalah. Jihad sekarang adalah jihad dalam bentuk peningkatan kualitas pendidikan dan ekonomi umat. Dengan cara inilah, Islam akan tampak di mata dunia sebagai agama yang memperjuangkan kedamaian dan toleransi yang sesuai dengan hakikat manusia sejati yang anti terhadap radikalisme. 


\section{BIBLIOGRAFI}

Aseri, Akh. Fauzi, Euthanasia, Suatu Tinjauan dari Segi Kedokteran, Hukum Pidana, dan Hukum Islam, dalam Problematika Hukum Islam Kontemporer, Editor: Dr. H. Chuzaimah Yanggo, T. dan HA. Hafiz Anshary AZ., MA., Jakarta: Pustaka Firdaus dan LSIK, cet. III, Maret 2002.

al-Bashri, Abu al-Hasan Ali bin Muhammad bin Habib al-Mawardi, al-Nukat wa al-Uyun Tafsir al-Mawardi, Beirut Libanon: Muassasah al-Kutub al-Tsaqafiyyah dan Darul Kutub al-Ilmiyyah, Jilid 1

al-Bajuri, Ibrahim, Hasyiyah al-Bajuri, Surabaya: Maktabah Shohabah Ilmu, tt. Juz 2.

Ali, As’ad Said, Negara Pancasila Jalan Kemaslahatan Bangsa, Jakarta: LP3ES, cet. 2, 2009.

Bin 'Asyur, Imam Muhammad Thohir, Tafsir al-Tahrirwa al-Tanwir, Tunisia : Darul Jamahiriyyah li al-Nasyr wa al-Tazi' wa al-I'lan, Juz 3-5.

Fanani, Ahwan, Liberalisme Islam Di Indonesia, Semarang: Pustaka Zaman \& Fakultas Ilmu Tarbiyah dan Keguruan IAIN Walisongo, 2013.

Hijazi, Muhammad Mahmud, Tafsir Wadlih, Beirut Libanon: Darul Fikri, Juz 1-10.

al-Jawi, Muhammad Nawawi, Marah Labib al-Tafsir al-Munir, Surabaya: Al-Hidayah, tt. Juz 1.

al-Mahalli, Al-Jalal Syamsuddin Muhammad bin Ahmad, Hasyiyah al-Allamah al-Bannani ala matni Jami al-Jawami, Jakarta: Daru Ihyail Kutub al-Arabiyyah Indonesia, tt. Juz 2

al-Maraghi, Tafsir al-Maraghi, Beirut Libanon: Darul Fikri, Juz 2, 2006.

al-Nawawi, Hasan Sulaiman dan Alawi Abbas al-Maliki, Ibanah al-Ahkam Syarhu Bulughil Maram, Beirut Libanon: Darul Fikri, Juz 2, 2004.

al-Qurtubi, Abu Abdillah Muhammad bin Ahmad al-Anshari, al-Jami li Ahkam al-Qur'an, Kairo: Darul Hadits, Juz 3, 2002.

Ridla, Muhammad Rasyid, Tafsir Manar, Beirut Libanon: Darul Kutub al-Ilmiyyah, Juz 5, 1999.

Syatha, Abu Bakar, I'anah al-Tholibin ala Hilli Alfadhi Fathil Mu’in, Jakarta: Daru Ihyail Kutub al-Arabiyyah Indonesia, Juz 4, tt.

al-Syafi'i, Sulaiman bin Umar al-Ujaili, al-Futuhatul Ilahiyyah Bi Taudlihil Jalalain li al-Daqoiq al-Khofiyyah, Beirut Libanon: Darul Kutub al-Ilmiyyah, Juz 2, 1996.

al-Thobrasi, Abu Ali al-Fadhl bin Hasan, Majma' al-Bayan fi Tafsir al-Qur'an, Beirut Libanon: Mafafturat Daru Maktabah al-hayat, Jilid 2, tt. 
al-Thusi, Abu Ja'far Muhmmad bin Hasan, al-Tibyan fi Tafsir al-Qur'an, Beirut Libanon: Daru Ihyai al-Turats al-Arabi, Jilid 3, tt.

Wahid, Abdurrahman, Universalisme Islam dan Kosmopolitanisme Peradaban Islam, dalam bukku Islam Universal, Yogyakarta: Pustaka Pelajar, 2007.

al-Zuhaili, Wahbah, al-Tafsir al-Munir fi al-Aqidah wa al-Syari'ah wa al-Manhaj, Beirut Libanon: Darul Fikri, Juz, 5-6, 1998.

Ushul al-Fighi al-Islami, Beirut Libanon: Dar al-Fikri, cet. 14, Juz 2, 2005. 
